searchers or project managers identified in the course of the survey, and representatives of donor agencies and policy making bodies. In a week of intensive discussion the seminar will strengthen links between those working in the field and the donor or policy making agencies; foster links between anglophone and francophone organizations and between the different social science disciplines involved. It will indicate the relevance of recent research to policy making and will provide guides for future research; it will contribute to the development of appropriate evaluation systems to monitor the progress of development projects designed to alleviate the effects of famine and drought.

\title{
Amnesty International's International Campaign to Abolish the Death Penalty
}

On April 25th Amnesty International began its international campaign to Abolish the Death Penalty. This campaign will continue through the rest of the year and will target death penalty practices in the United States, China, Iran, Iraq and the Soviet Union, as well as in two African countries, Nigeria and South Africa.

Nigeria: The death penalty in Nigeria has been a major concern to Amnesty International for many years. AI has taken up the issue with govemment officials, target sectors and others through direct approaches from AI's Secretary General and various other AI actions. These has been a mixed response from government officials and individuals in Nigeria, some of it positive. The military government that came to power in August 1985 has restricted the scope of the death penalty by repealing certain death penalty legislation and the number of executions is believed to have declined since then. The high incidence of armed robbery, however, is a very real issue of concern among Nigerians and has been one of the principal reasons why the government has retained the death penalty for this offense. During the campaign, certain aspects of the death penalty in Nigeria will be singled out for special attention in the hope of positive results which may lead to the abolition of the death penalty in the long-term. These special issues of concern are: high number of death sentences and executions; death sentences imposed with no right of appeal; children under 18 at the time of the offense may be executed; and public executions.

South Africa: Executions have exceeded one hundred a year in South Africa in recent years, and the percentage of death sentences commuted by the authorities has declined. In 1988 there were 117 reported executions, excluding those in the nominally independent "homelands;" and in 1987 there was a total of at least 172 executions in the whole of South Africa, the highest figure since independence in 1910. Death sentences are imposed disproportionately on the black population by an almost entirely white judiciary (of the people executed in 1987, 163 were black and 9 white). South African lawyers have criticized the inadequacies of the legal aid system, the lack of automatic right of appeal and other procedural issues which prejudice the position of poor, mostly black defendants. The death penalty is increasingly imposed at political trials or trials for politically-related killings. Defendants in these cases are often held incommunicado for long periods before being brought to trail; some have been physically tortured, and statements they or others have made during prolonged periods of incommunicado detention often form the basis of the prosecution's evidence against them. 
The West African and the South African Coordination Groups of the US section of Amnesty International are organizing campaign strategies to mobilize Amnesty members and interested groups towards working against the death penalty in Nigeria and South Africa. One objective is to reach out to the Africanist academic community and develop a network of contacts willing to participate in campaign activities this fall.

If you are interested, please contact: Wayne Heimbach, West African Coordination Group, 4923A Crain, Skokie, IL 60077, (312) 676-0814, (FOR NIGERIA); or Susan Riveles, South African Coordination Group, 9007 Garland Avenue, Silver Spring, MD 20901, (301) 585-6428, (FOR SOUTH AFRICA).

\section{NEW PUBLICATIONS FROM OVERSEAS}

The Centre of West African Studies, University of Birmingham, is beginning a series of collections of interdisciplinary papers on a variety of African themes. The first in the series, entitled Discourse and its Disguises: the Interpretation of African Oral Texts, brings together history, anthropology, and literary theory to throw fresh light on theoretical issues in the interpretation of oral texts. The cases discussed, drawn from West and Southern Africa, include hitherto unpublished ethnographic material on a number of oral genres and their social and historical backgrounds.

Order from Dr. P. F. de Moracs, Centre of West African Studies, University of Birmingham, P. O. Box 363, Birmingham, B15 2TT, England.

Cost: UK: $£ 6.95$; Europe: $£ 8.70$; and US: $\$ 17.50$ (second class postage) or $\$ 24.00$ (first class postage).

The Human Resources Research Centre of the Faculty of Education, University of Zimbabwe, announces the establishment of a new journal, Zimbabwe Journal of Educational Research. The journal is directed at educators and researchers involved in economic development. There will be three issues each year.

For information, contact: Editor, ZJER, HRRC Faculty of Education, University of Zimbabwe, Post Office Box MP 167, Mount Pleasant, Harare, Zimbabwe, or Editor, ZJER, Learning Systems Institute, 204 Dodd Hall, Florida State University, Tallahassee, FL 32306.

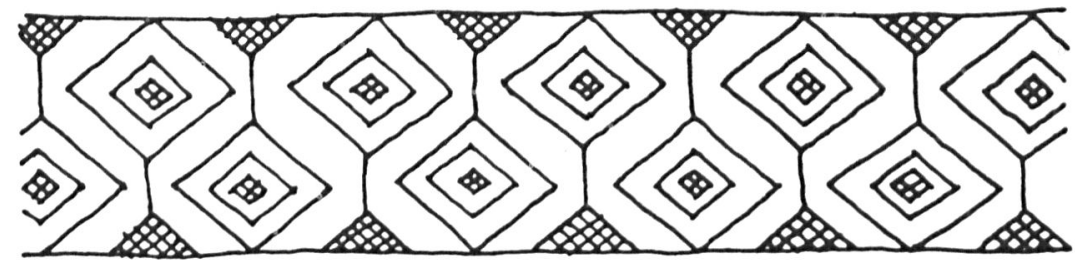

